\title{
INTERORGANIZATIONAL LEARNING AND ABSORPTIVE CAPACITY: EMPIRICAL RESEARCH IN SMALL AND MEDIUM ENTERPRISES
}

\author{
ALESSANDRA CASSOL ${ }^{1}$ \\ http://orcid.org/0000-0003-0753-9642 \\ MÁRCIO L. MARIETTO \\ https://orcid.org/0000-0003-1526-6058 \\ GRACIELE TONIAL ${ }^{3}$ \\ https://orcid.org/0000-0001-5137-035X \\ NATHALIA B. WERLANG ${ }^{4}$ \\ http://orcid.org/0000-0003-0172-6025
}

To cite this paper: Cassol, A., Marietto, M. L., Tonial, G., \& Werlang, N. B. (2021). Interorganizational learning and absorptive capacity: Empirical research in small and medium enterprises. Revista de Administração Mackenzie, 22(1), 1-28. doi:10.1590/1678-6971/eRAMR210035

Submission: Mar. 14, 2019. Acceptance: Jan. 22, 2020.

\footnotetext{
University of Contestado (UnC), Concórdia, SC, Brazil.

2 Polytechnic Institute of Leiria (ESTG), Leiria, Portugal.

3 University of Western Santa Catarina (Unoesc), Joaçaba, SC, Brazil.

4 FAI University Center, Itapiranga, SC, Brazil.
} 


\section{ABSTRACT}

Purpose: This research analyzes the influence of interorganizational learning (IOL) on the absorptive (Acap), potential (Pacap) and realized (Racap) capacities on the environment of small and medium enterprises (SMEs).

Originality/value: The study contributed to the understanding and expansion of IOL research operationalized through the elements of Acap. The understanding of these elements are fundamental for the development of competencies of SMEs from Brazil and/or emerging countries embedded on dynamic sectors and high technology mobility to adapt and develop new dynamic capabilities.

Design/methodology/approach: The research was conducted by a survey with a sample of 215 organizations of the information technology and communication (ITC) sector in the State of Santa Catarina, Brazil. The data were analyzed using the structural equation modeling technique.

Findings: The results showed that the relationships of IOL influence the development of new capabilities and have a strong influence over absorptive capacity development. The organizations ability to acquire, assimilate, apply and internalize the available knowledge in the sector through interorganizational relations was fundamental for their adaptation and survival.

\section{KEYWORDS}

Organizational learning. Interorganizational learning. Absorptive capacity. Small and medium enterprises. Information and communication technology sector. 


\section{INTRODUCTION}

The dynamics of absorptive capacity (Acap) have a strong relationship with organizational learning (OL) processes. Their construction is based on learning processes that are directed toward the exploration, assimilation, transformation, and application of external knowledge (Camisón \& Forés, 2010; Lane, Koka, \& Pathak, 2006). Consequently, the formation and development of Acap also depend on the stability and robustness of the learning environment in the organization, in which the intra and interorganizational learning practices stand out (Gebauer, Worch, \& Truffer, 2012). The objective of this research is to analyze the influence of interorganizational learning (IOL) on Acap. In addition, the following are proposed: 1 . to verify if there is influence of IOL on the potential absorptive capacity (Pacap); b) to check if there is influence of IOL on the realized absorptive capacity (Racap).

Organizations depend on external knowledge and their Acap to improve their performance and guarantee their survival and adaptation to the dynamism of the market to which they belong. The effort to absorb external knowledge varies according to the conditions of the environmental context in which the organizations are inserted (Koerich, Cancellier, \& Tezza, 2015). Naturally, for small and medium-sized enterprises (SMEs) located in developing countries, IOL plays a fundamental role in the Acap to provide minimum elements of organizational survival (Ernst, 2010; Zonta \& Amal, 2017). These attributes become even more relevant if SMEs are located in dynamic and highly technologically mobile sectors, such as information and communication technology (ICT).

In the case of Brazil, this gap is even more evident, since Acap studies found in the literature are mainly characterized as theoretical and are concentrated in the context of large companies (Koerich \& Cancellier, 2017). There is a strong domain of research on Acap in environments of developed economies (Flatten, Greve, \& Brettel, 2011), highlighting the need for research in emerging countries like Brazil. We also observed that few studies have analyzed Acap in the SMEs environment (Cassol, Gonçalo, \& Ruas, 2016; Cassol, Zanesco, Martins, \& Marietto, 2019), which further exacerbates this gap, considering the importance of this type of company for the country. For SMEs, Acap is significant because it depends on the organization's ability to develop and expand the organizational knowledge base quickly and effectively (Flatten, Engelen, Zahra, \& Brettel, 2011). Considering this, we seek to understand the problem between IOL and Acap in the envi- 
ronment of ICT SMEs, in order to contribute to fill the research gap on Acap in SMEs in Brazil and in emerging countries. Our intention is to answer the following research question:

- What is the influence of IOL on Acap?

The dynamics of the performance of technology organizations characterize them as intensive in innovation and knowledge (Teixeira, Oliveira, \& Curado, 2018). They are also organizations in which knowledge sharing and development are critical factors for their existence and for the quality of organizational results (Nonaka \& Von Krogh, 2009). From this premise, it is assumed that companies characterized as being within the ICT sector have a great challenge in the transformation of knowledge from IOL and in the development of new capacities.

This article is structured in the following order: in addition to this introduction, the theoretical framework that supports the hypotheses is described, then the methodological procedures, the data and results analysis, and, lastly, the final considerations are all presented.

\section{THEORETICAL FRAMEWORK AND HYPOTHESES}

This section provides theoretical support for the hypotheses proposed for this research, arising from the theory of IOL and Acap.

\subsection{Interorganizational learning in the SME ecosystem of the ICT sector}

OL is the process by which organizational actions and routines are modified and improved, based on an existing prior knowledge base (Fiol \& Lyles, 1985) combined with the acquisition of new knowledge and the distribution and interpretation of information. The learning process in organizations is responsible for transforming the knowledge created by an individual into actions focused toward organizational objectives (Easterby-Smith \& Lyles, 2011).

The OL literature points to two main analytical approaches, the first of which is intra-organizational learning, which deals with learning within organizations and makes reference to learning based on the formal and integrated experiences of individuals who share different knowledge bases and learn in a shared way (Fiol \& Lyles, 1985; Crossan, Lane, \& White, 1999; 
Argote \& Ophir, 2002; Holmqvist, 2003). The second approach, IOL, analyzes the learning relationships between organizations, and seeks to explain how knowledge acquisition occurs between actors and groups of organizations (Larsson, Lars Bengtsson, \& Sparks, 1998; Cooper \& Rousseau, 1999; Child, 2001). It also deals with the importance of access to knowledge through the interaction between different actors in interorganizational networks, considering the link of the organization with other members of its network as an important element in learning (Wang \& Zhang, 2009).

Formal, and often informal collaboration between organizations, as well as interaction between different agents, also provides IOL in the SME environment. It appears that interorganizational collaborative actions in their most varied forms are related to a series of important results. These include sharing, knowledge transfer, and the creation of new knowledge capable of providing new solutions for the market (Mozzato, Bitencourt, \& Grzybovski, 2015). IOL in the SME environment directly impacts the performance of organizations, since it is able to provide a continuous flow between the existing knowledge in the organization and the new knowledge arising from interorganizational action. For SMEs, the relationship with long-term alliance partners can generate common benefits. The products of acquired mutual learning increase the commitment, reciprocity, and stability of alliances. (Fredrich, Bouncken, \& Kraus, 2018).

This research treats OL based on the interorganizational approach (IOL), based on the concept that the learning process between organizations occurs through network activities, strategic alliances, formal collaboration, and through the interaction between different agents (Child, 2001; Holmqvist, 2003; Wang \& Zhang, 2009; Ernst, 2010; Crossan, Mauer, \& White, 2011; Mozzato \& Bitencourt, 2014; Zonta \& Amal, 2017). We argue that interorganizational relations between SMEs participating in networks, strategic alliances, clusters, or local productive arrangements promote the best performance of these organizations. The relationships established in such configurations tend to result in interorganizational interaction and learning. Even if competition between companies in the same sector is not denied, cooperation strategies have become a source of competitive advantage (Ernst, 2010; Mozzatto \& Bitencourt, 2014).

\subsection{Absorptive capacity (Acap)}

Acap incorporates, in many aspects, the concept of dynamic capabilities (DC) introduced by Teece, Pisano, and Shuen (1997). DC represents a high 
level of capability that allows organizations to continually reconfigure themselves through the accumulation of knowledge and respond more quickly and effectively to changes in the markets. Such a capability requires organizations to analyze their environment and then filter and appropriate external knowledge, so that it guides their future actions (Cassol et al., 2019). Therefore, Acap is represented by the ability of organizations to identify and assimilate knowledge available in the interorganizational environment, and based on the reconfiguration of existing prior knowledge, to create new organizational routines and processes effective in promoting a DC. Consequently, through Acap, the organization is able to take advantage of preexisting knowledge within it, combined with knowledge acquired from external sources, transforming it into new resources and capacities (Cohen \& Levinthal, 1990).

Acap mainly depends on the sharing of knowledge within an organization, or more accurately, on its Pacap, not solely depending on relationships with the external environment (Cohen \& Levinthal, 1990). Acap depends on processes and routines from within the organization, that allow for the communication, sharing, and transferring of knowledge (Lane et al., 2006). Consequently, it plays an important role in achieving a balance between exploring resources and capacities resulting from interorganizational interaction, since it allows organizations to access new knowledge, new partnerships, and new market niches (Ferreira \& Ferreira, 2017).

Zahra and George (2002) proposed a reconceptualization of the term Acap. The multidimensional concept proposed by said authors asserted that Acap is composed of the capacities of identification, assimilation, transformation, and application of knowledge for commercial purposes. The authors indicated that Acap is divided into two different subsets; 1. Pacap, which involves the dimensions of knowledge acquisition and assimilation; and 2. Racap, which emphasizes the dimensions of transformation and application of knowledge (Zahra \& George, 2002). These two different subsets defined by the authors are relevant and need to be investigated, since they involve different organizational contexts. An organization may be quite capable of understanding complex technical problems (acquisition and assimilation), but might not be able to use this knowledge (transform and apply).

\subsubsection{Potential Absorptive Capability (Pacap)}

Pacap, for Flatten et al. (2011), is verified by: 1. acquisition, which is defined as the ability to identify and obtain external knowledge and infor- 
mation; and 2. assimilation, which refers to the organization's routines and processes that allow analysis, understanding, and interpretation of information and knowledge acquired externally. This flow of knowledge acquisition and assimilation supports Pacap within organizations. Current studies, such as Flatten et al. (2011), Schildt, Keil, and Maula (2012); Otto (2012), Song (2015); Picoli and Takahashi (2016), and Apriliyanti and Alon (2017) seek to empirically prove the relationship between IOL and Pacap, in addition to suggesting that new studies should seek to understand the role of IOL in the acquisition and assimilation of knowledge.

The relationship between IOL and Pacap, through interorganizational strategic alliances, occurs based on the trust developed by the organizations participating in the network. The knowledge acquired in collaborative work provides new organizational views that can support different strategies (Otto, 2012), strengthening Pacap. The acquisition of knowledge from strategic alliances is relevant, since networks affect the strategies of organizations with regard to the search for external knowledge, and, consequently, are influenced by the learning process. Thus, multiple interorganizational relationships enable an organization to improve its performance due to its ability to acquire external knowledge from its networks (Apriliyanti \& Alon, 2017) and internalize it through Pacap.

Pacap depends on the level of previous knowledge that the organization has, primarily, if this knowledge is developed and accumulated through IOL processes. In the knowledge acquisition stage, the first phase of Pacap, the company's previous knowledge becomes vital. Based on the expertise of employees, the use of problem solving methods and shared communication, the organization is able to more effectively recognize which external knowledge is important to it (Patterson \& Ambrosini, 2015).

Intrinsic to the Pacap dimension, the assimilation process is considered an essential component in OL and is an integral factor for competitive advantage (Fletcher \& Prashantham, 2011). This is because organizations operate in networks seeking to internalize valuable and strategic resources and also to improve IOL (Jung-Erceg, Pandza, Armbruster, \& Dreher, 2007). Thus, the knowledge assimilated by the organization is not limited to a single individual, but it depends on interactions and sharing between individuals (Jansen, Van Den Bosch, \& Volberda, 2005; Caccia-Bava, Guimarães, \& Harrington, 2006). This leads to knowledge transfer (Sparrow, Tarkowski, Lancaster, \& Mooney, 2009), which is supported by IOL.

SMEs have different characteristics in relation to their organizational structure and configuration with difficulties in capturing, assimilating, and 
managing external knowledge. They seek to strengthen themselves through their relationships with partners (Ireland, Hitt, \& Vaidyanath, 2002; Tracey \& Clark, 2003), which are supported by IOL practices. In organizations present in emerging countries, Acap and IOL are strongly related (Jain, Kashiramka, \& Jain, 2018; Fredrich et al., 2018), as IOL precedes Pacap. Therefore, the following is proposed:

- Hypothesis 1: IOL of SMEs in the ICT sector is positively related to Pacap.

- H1a: IOL of SMEs in the ICT sector is positively related to the ability to acquire knowledge.

- H1b: IOL of SMEs in the ICT sector is positively related to the ability to assimilate knowledge.

\subsubsection{Realized absorptive capacity (Racap)}

Acap's development is enhanced when the organization establishes links with other organizations, as these are sources of knowledge that can expand its existing know-how and also upskill its employees with new experiences. However, organizations need to develop Racap, or rather, transform and apply the knowledge acquired in order to use these results for commercial purposes (Zahra \& George, 2002; Vinding, 2006; Song, 2015; Picoli \& Takahashi, 2016; Oliveira \& Balestrin, 2018). Racap can be improved using IOL practices, which can be perceived with different forms of intensity, depending on the structure of the organization. Thus, the value created due to the absorbed knowledge will result in an increase in performance (Koçoglu, Akgün, \& Keskin, 2015).

Knowledge transformation refers to the organizational capacity to refine and develop processes that favor the combination of existing knowledge with external and assimilated information. Knowledge application is related to the organizational capacity to create, incorporate, and use the information and knowledge acquired by the company in the previous stages of assimilation and transformation of knowledge (Flatten et al., 2011). New knowledge acquired through the learning process needs to be assimilated and transformed in order for the organization to develop new capacities from Acap. Thus, the learning process must occur in an effective manner, since if the acquired knowledge is not integrated or transformed through Acap, the result of the application may not be significant to the organization (Song, 2015). 
In the context of organizations in the Brazilian technology sector, the Acap process takes place continuously and by OL through mechanisms of social integration. The flow of knowledge is considered a key element both in OL and in all stages of Acap. However it is understood that knowledge may not be absorbed in the same way among organizations that belong to the same environment, since each have their own particularities in the internalization of knowledge (Picoli \& Takahashi, 2016). Therefore, it is appropriate to understand the relationship between the capacity of IOL, and Racap.

Developing favorable conditions for the appropriation of knowledge from interorganizational networks, through the construction of new capacities and the relationship with individual knowledge that already exists internally, becomes the central role of organizations. The same can be proposed about the application of this new knowledge that promotes the development of new skills (Cassol et al., 2019). We deduce that it is possible to understand that IOL occurs from the interaction of organizations with other actors, and that this relationship can influence the development of the Racap. Therefore, the following is proposed:

- Hypothesis 2: IOL of SMEs in the ICT sector is positively related to Racap.

- H2a: IOL of SMEs in the ICT sector is positively related to the capacity for knowledge transformation.

- H2b: IOL of SMEs in the ICT sector is positively related to the capacity to apply knowledge.

\section{METHODOLOGICAL PROCEDURES}

This research seeks to understand the influence of IOL on Pacap and Racap in the environment of SMEs in the ICT sector in the state of Santa Catarina. As a research method, we used a survey with questionnaires validated in national and international studies with which pre-tests were carried out previously. All constructs of the research instrument were measured using a seven-point Likert scale, with response options ranging from "strongly disagree (1)" to "strongly agree (7)".

Data was collected from SMEs in the ICT sector located in the state of Santa Catarina, with up to 99 employees, according to criteria defined by the Brazilian Micro and Small Business Support Service (Sebrae, 2017). The questionnaires were sent online. 
For greater precision in estimating a minimum sample size, the $G^{*}$ Power 3.1.9.2 program was used. The sample's power was assessed considering the a priori calculation of data collection (Faul, Erdfelder, Lang, \& Buchner, 2007). The minimum sample size suggested by $G *$ Power was 55 cases, but as a suggestion to have a more consistent model, it would be interesting to use double or triple that number of cases (Ringle, Silva, \& Bido, 2014). Thus, the sample size of the survey was 215 respondents, providing statistical power to detect the existence of a supposed relationship between the variables investigated. The sample was characterized as simple probabilistic, in which statistical parameters were adopted in order to ensure that all elements were chosen at random (Rea \& Parker, 2000), with an equal probability of being selected.

The sample was characterized by mostly male respondents $(70 \%)$ with undergraduate or graduate degrees $(65 \%)$, of up to 35 years of age $(81 \%)$. Of the total sample, $28.37 \%$ act as administrators, and $71.63 \%$ exercise leadership functions. Most of the companies investigated (54\%) have been active in the market for less than 10 years. From the respondents, we obtained the following distribution: $47.9 \%$ are organizations that work with activities related to information technology services, $15.8 \%$ work in activities providing information services, and $8.9 \%$ work in other activities related to the investigated sector.

As an independent variable, the construct of IOL was defined according to Holmqvist (2003). The variables proposed to measure the construct of IOL come from the study by Valentin (2010), which is supported by Holmqvist (2003), and Jones and Machperson (2005), having been evaluated and validated by a group of specialists and professionals who work in organizations that operate in information, and scientific and technical knowledge networks. Figure 3.1 shows the variables used to measure the construct of IOL:

\section{(Figure 3.1)}

\section{VARIABLES OF THE IOL CONSTRUCT}

AlO1 - Cooperative networking with other organizations strengthens our company's strategy.

AlO2 - Cooperative networking with other organizations increases the visibility of our company.

Al03 - Cooperation and participation in networks strengthens our company's strategy.

AlO4 - Cooperation and participation in thematic information and knowledge networks strengthens our company's strategy.

Al05 - Networking helps to update and develop our company's methodologies. 


\section{(Figure 3.1 (conclusion))}

VARIABLES OF THE IOL CONSTRUCT

\begin{tabular}{l}
\hline Al06 - Networking helps to update and develop our company's technologies. \\
\hline Al07 - Networking contributes to our company adopting innovative methodologies. \\
\hline Al08 - Networking contributes to our company adopting innovative technologies. \\
\hline Al09-Products and services produced and used cooperatively and in a network are more \\
effective.
\end{tabular}

Al010 - Public goods produced cooperatively and in a network are more effective.

Source: Valentin (2010), Holmqvist (2003), and Jones and Machperson (2005).

As a dependent variable for understanding the context of Acap, the questionnaire validated in the research by Flatten, Engelen et al. (2011) was adapted. The authors recommended a multidimensional measure composed of the dimensions of acquisition, assimilation, transformation, and application through their survey carried out with 360 German companies from intensive research sectors, given that Acap is especially important for this type of organization. The authors argued that future research is necessary in order to raise and develop factors and new instruments for measuring Acap in different countries and sectors, other than industry, of which most of the existing studies are focused on. In Brazil, the scale was translated, adapted, and applied by Koerich et al. (2015), with 230 retail companies in the Greater region of Florianópolis. Figure 3.2 presents the research variables.

\section{(Figure 3.2)}

DIMENSIONS AND VARIABLES OF THE ACAP CONSTRUCT

\begin{tabular}{|c|c|}
\hline & Variables \\
\hline \multirow{4}{*}{ 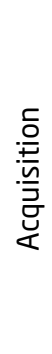 } & $\begin{array}{l}\text { AQ1 - Our management stimulates the exchange of information and experiences with other } \\
\text { companies in the same sector. }\end{array}$ \\
\hline & $\begin{array}{l}\text { AQ2 - Our management engages in joint research projects with other companies or research } \\
\text { institutions. }\end{array}$ \\
\hline & $\begin{array}{l}\text { AQ3 - We hold periodic meetings with external experts to accumulate relevant information for our } \\
\text { company. }\end{array}$ \\
\hline & AQ4 - The search for pertinent information about our sector is common in our company. \\
\hline
\end{tabular}

(continue) 


\section{(Figure 3.2 (continuation))}

\section{DIMENSIONS AND VARIABLES OF THE ACAP CONSTRUCT}

\begin{tabular}{|c|c|}
\hline & Variables \\
\hline \multirow{3}{*}{ 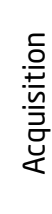 } & $\begin{array}{l}\text { AQ5 - Our management motivates employees to use other sources of information within the } \\
\text { company. }\end{array}$ \\
\hline & AQ6 - We like it when employees acquire information from other sectors as well. \\
\hline & AQ7 - Management expects employees to handle information beyond our area of expertise. \\
\hline \multirow{12}{*}{ 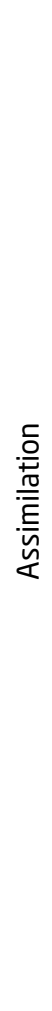 } & AS8 - In our company, ideas and concepts are communicated between sectors. \\
\hline & AS9 - Our management stimulates support between sectors to solve problems. \\
\hline & $\begin{array}{l}\text { AS10 - Our company uses tools (for example the intranet, internal studies/reports) to spread } \\
\text { knowledge throughout the organization. }\end{array}$ \\
\hline & $\begin{array}{l}\text { ASI1 - In our company, there is a fast flow of information, for example, if one sector obtains } \\
\text { important information it immediately communicates that information to all other sectors. }\end{array}$ \\
\hline & $\begin{array}{l}\text { AS12 - Our management holds meetings with all sectors periodically to exchange new knowledge, } \\
\text { problems, and achievements. }\end{array}$ \\
\hline & $\begin{array}{l}\text { AS13 - Our employees from different sectors do very well when communicating with each other on } \\
\text { an interdepartmental basis. }\end{array}$ \\
\hline & $\begin{array}{l}\text { AS14 - For projects, our management supports the temporary exchange of people between } \\
\text { sectors. }\end{array}$ \\
\hline & AS15 - In our company, there is informal contact between employees at all levels and sectors. \\
\hline & AS16 - Our management encourages a common language for communication within the company. \\
\hline & $\begin{array}{l}\text { AS17 - In our company, employees are aware of who has special skills and knowledge and to whom } \\
\text { certain information is relevant. }\end{array}$ \\
\hline & $\begin{array}{l}\text { AS18 - Our employees willingly share their knowledge, information, and experience with } \\
\text { colleagues. }\end{array}$ \\
\hline & AS19 - Our company is a good model in relation to the distribution of knowledge. \\
\hline \multirow{6}{*}{ 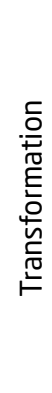 } & TR20 - Our employees have the ability to structure and use the knowledge acquired. \\
\hline & TR21 - Our management encourages the systematic reuse of ideas from previous projects. \\
\hline & TR22 - Our policy encourages employees to participate in continuous training and learning. \\
\hline & TR23 - Our employees are encouraged to absorb new knowledge, as well as use it. \\
\hline & TR24 - Our employees successfully link existing knowledge to new insights. \\
\hline & $\begin{array}{l}\text { TR25 - Our employees skillfully transform information from internal and external sources into } \\
\text { valuable knowledge for our company. }\end{array}$ \\
\hline
\end{tabular}




\section{(Figure 3.2 (conclusion))}

DIMENSIONS AND VARIABLES OF THE ACAP CONSTRUCT

\begin{tabular}{l|l}
\hline \multicolumn{2}{c}{ Variables } \\
\hline \multirow{2}{*}{$\begin{array}{l}\text { TR26 - Our management encourages employees to combine/exchange ideas between different } \\
\text { sectors. }\end{array}$} \\
\cline { 2 - 2 } & TR27 - Our management believes that our learning skills are a competitive advantage for our \\
company.
\end{tabular}

Source: Adapted from Flatten, Engelen et al. (2011).

Data processing and analysis were performed using the SPSS statistics software version 22.0 for descriptive analysis, and Smart PLS 3.0 (Ringle, Wende, \& Will, 2005) for the analysis of the relationships between the latent variables (LVs). We opted for the technique of structural equation modeling (SEM) based on partial least square (PLS) adjustment estimation models, as shown in Figure 3.3. The use of PLS-SEM allows the testing of causal paths between second-order LVs, in addition to offering extensive, scalable, and flexible causal modeling capacities (Lowry \& Gaskin, 2014). The technique is recommended for more complex models, or rather, those with high quantities of constructs and observed variables (Ringle et al., 2014), and with less data, as noticed in this research.

To meet the objectives of this study, Acap was estimated with a reflective model for the second order LVs, which were modeled according to the hierarchical components approach (Wetzels, Odekerken-Schröder, \& Van Oppen, 2009; Hair, Hult, Ringle, \& Sarstedt, 2016). The reflective model 
for Acap was used in previous studies (Flatten, Engelen et al., 2011; LealRodríguez, Ariza-Montes, Roldán, \& Leal-Millán, 2014; Hernández-Perlines, Moreno-García, \& Yáñez-Araque, 2016).

\section{(Figure 3.3)}

\section{THEORETICAL MODEL OF THE HYPOTHESES}

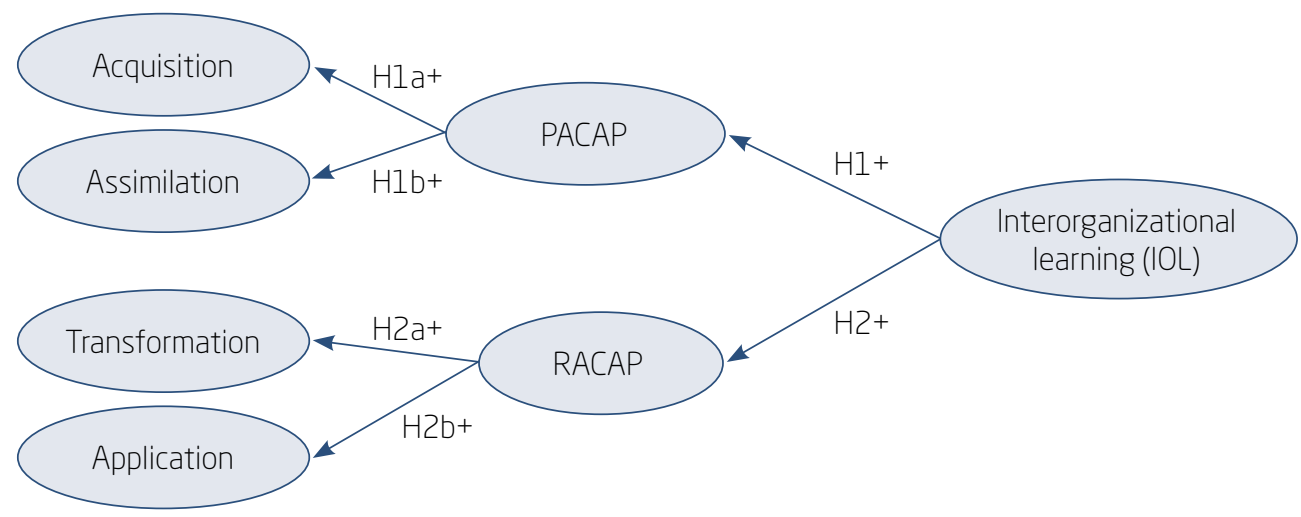

Source: Elaborated by the authors.

\section{PRESENTATION OF THE RESULTS}

The LVs of this study were modeled in a reflexive way (Wetzels et al., 2009; Hair et al., 2016). To evaluate the measurement model, all indicators were initially used to measure the constructs, and the criteria proposed by the literature were followed. Convergent validity (AVE $>0.5)$, discriminant validity by the Fornell-Larcker criterion, Cronbach's alpha reliability (CA > 0.7 ), and composite reliability ( $\mathrm{CR}>0.7$ ) were analyzed (Ringle, Sarstedt, \& Straub, 2012; Hair et al., 2016; Henseler, Ringle, \& Sinkovics, 2009; Hair, Black, Babin, Anderson, \& Tatham, 2009).

After the analysis of the Betas, some variables were excluded from the model, being; three variables of the acquisition dimension in the Pacap construct $(\mathrm{AQ} 1=0.543 ; \mathrm{AQ} 2=0.443 ; \mathrm{AQ} 3=0.645)$ and six variables of the assimilation dimension (AS13 $=0.511$; AS14 $=0.457$; AS15 $=0.557$; AS16 $=0.645 ;$ AS17 $=0.534$; AS18 = 0.453). In the Racap construct, three variables of the transformation dimension were excluded $(\mathrm{TR} 20=0.568$; TR21 $=0.621$; TR3 $1=0.613$ ) and no variables of the application dimension. Also, no variables in the IOL construct were excluded. 
From the analysis of convergent validity, discriminant validity, and reliability validity, the results indicated a positive evaluation of the measurement model. Thus, it is possible to affirm that the LVs were adequately measured and the variables that remained in the model fulfill the requirements of validity and reliability, as shown in Figure 4.1.

(Figure 4.1)

CORRELATION MATRIX BETWEEN LATENT VARIABLES

\begin{tabular}{llcccccccc}
\hline LV 2nd order & LV 1st order & AP & IOL & AQ & AS & TR & CA & CR & AVE \\
\hline & Application (AP) & 0.806 & & & & & 0.864 & 0.902 & 0.650 \\
\hline & $\begin{array}{l}\text { Interorganizational } \\
\text { learning (IOL) }\end{array}$ & 0.663 & 0.834 & & & & 0.951 & 0.958 & 0.696 \\
\hline & Acquisition (AQ) & 0.343 & 0.417 & 0.801 & & 0.813 & 0.877 & 0.641 \\
\hline & Assimilation (AS) & 0.490 & 0.521 & 0.706 & 0.798 & & 0.884 & 0.912 & 0.636 \\
\hline & Transformation (TR) & 0.528 & 0.588 & 0.598 & 0.658 & 0.782 & 0.921 & 0.934 & 0.612 \\
\hline Pacap & & & & & & 0.913 & 0.914 & 0.510 \\
\hline Racap & & & & & & 0.932 & 0.932 & 0.522 \\
\hline
\end{tabular}

CA: Cronbach's alpha; CR: composite reliability; AVE: average variance extracted (AVE).

Source: Elaborated by the authors.

The structural coefficients were calculated using the SmartPLS 3.0.M3 software (Ringle et al., 2005) and the p-values were estimated by bootstrap, considering a sample of 215 cases and 1000 resamples, so that confidence intervals could be obtained to evaluate the significance of the estimated coefficients. The results of the structural model are illustrated in Figure 4.2. 
(Figure 4.2)

FINAL STRUCTURAL MODEL

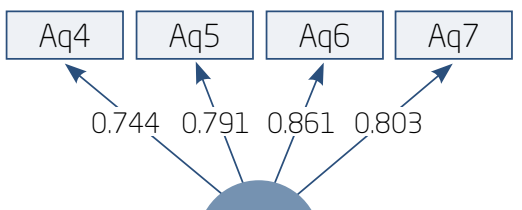

0.784

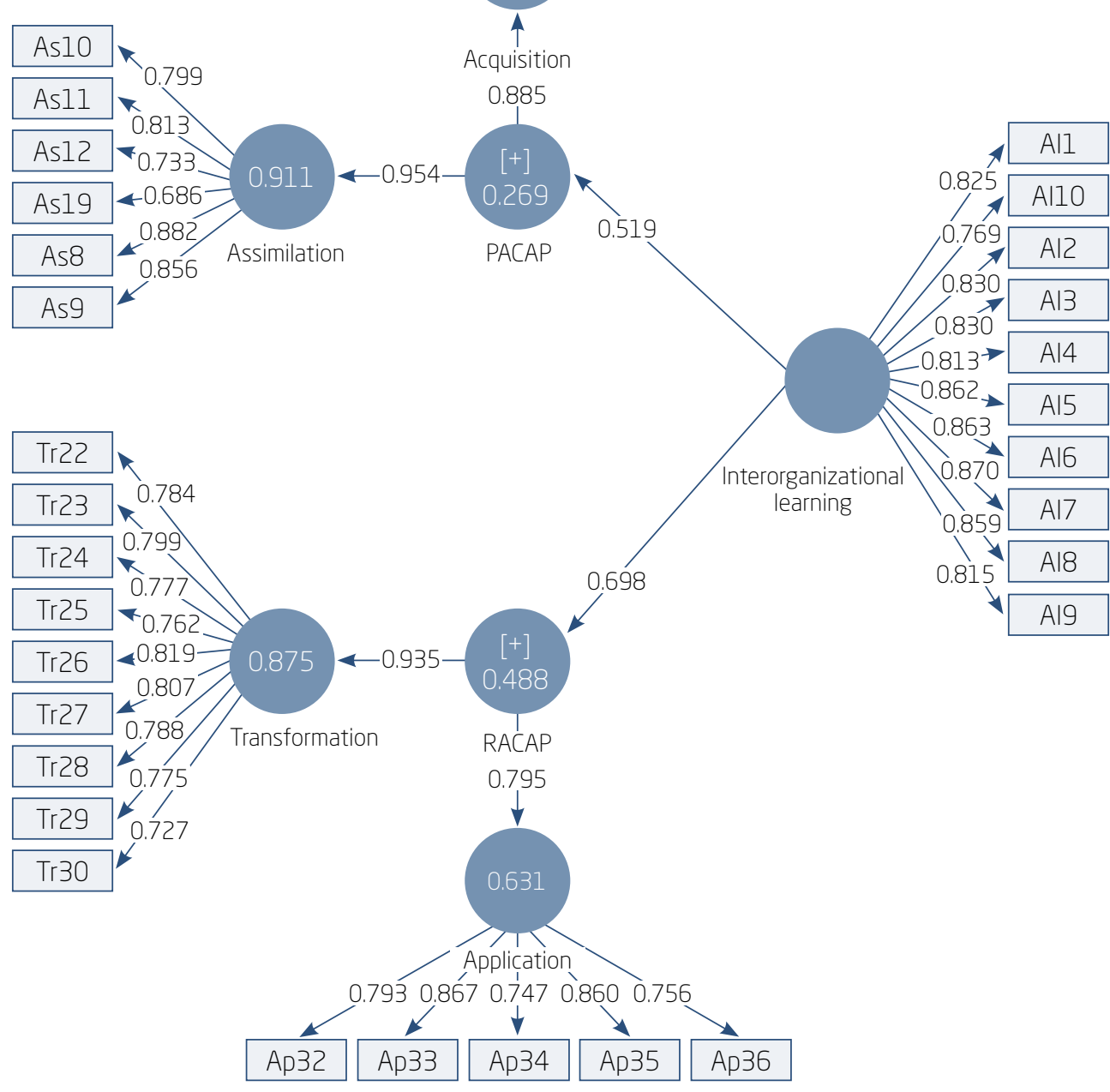

Source: Elaborated by the authors.

Figure 4.3 gathers the structural relations statistics. The path coefficients indicate how closely the constructs are related to each other. We 
observed the values of $\beta$, values ranging from -1.0 to +1.0 , respectively indicating a negative or positive relationship between two constructs (Hair, Sarstedt, Hopkins, \& Kuppelwieser, 2014). In the tested model, we observed a strong relationship between the studied constructs. For the Beta to be accepted, it is necessary to test the causal relationship between two constructs and check if it is significant or not. Therefore, we used the Student's t test $(t>1.96)$ (Hair et al., 2009).

\section{(Figure 4.3)}

PARAMETERS OF THE QUANTITATIVE RESEARCH STRUCTURE

\begin{tabular}{|c|c|c|c|c|c|}
\hline Hypotheses & $\begin{array}{c}\text { Relationship between } \\
\text { variables }\end{array}$ & $\beta$ & $\mathrm{t}$ test & $P$ values & Situation \\
\hline $\mathrm{HI}$ & IOL -> Pacap & 0.519 & 8.194 & 0.000 & Supported \\
\hline $\mathrm{Hla}$ & Pacap -> Acquisition & 0.885 & 47.059 & 0.000 & Supported \\
\hline $\mathrm{Hlb}$ & Pacap -> Assimilation & 0.954 & 128.693 & 0.000 & Supported \\
\hline $\mathrm{H} 2$ & IOL -> Racap & 0.698 & 16.395 & 0.000 & Supported \\
\hline $\mathrm{H} 2 \mathrm{a}$ & Racap -> Transformation & 0.935 & 77.415 & 0.000 & Supported \\
\hline $\mathrm{H} 2 \mathrm{~b}$ & Racap -> Application & 0.795 & 32.560 & 0.000 & Supported \\
\hline
\end{tabular}

Source: Elaborated by the authors.

The results support the hypothesis that the SMEs' IOL is positively related to Pacap, and, consequently, to the acquisition and assimilation of new knowledge. This relationship can be explained because SMEs that seek knowledge and learn from their partners become faster and more flexible to respond to the challenges of the competitive market in which they operate (Jiménez-Jiménez \& Sanz-Valle, 2011), which is seen in the environment in which technology companies operate.

From the variables that remained in the final model, it was possible to show some practices present in the routines of the investigated companies, because the respondents (managers) affirmed that their companies carry out these actions in their organizations. Regarding the practices related to Pacap in the acquisition of knowledge, companies usually seek information about their sector of activity and encourage employees to do the same. This happens with the participation of companies in collaboration networks, such as attending events, training, and presence in associations. When analyzing the ability to assimilate knowledge, we realized that the investigated 
companies have knowledge exchange practices between employees and sectors, such as periodic meetings to share new knowledge, problems, or results. Companies also make use of tools, such as intranets, internal studies, and reports to spread knowledge and information among all employees.

The second hypothesis also confirmed that the SMEs' IOL is positively related to the Racap, transformation, and to the application of the acquired and internalized knowledge. In this process, Racap evolves through IOL, as the higher the level of technical training, experience, and knowledge of employees over time, the better they will be able to assimilate and transform new learning into skills acquired in interorganizational relationships (Todorova \& Durisin, 2007).

When analyzing the practices present in the investigated companies, we observed that the capacity for knowledge transformation is verified through policies to encourage the training and continuous learning of employees. Companies promote the combination of ideas and knowledge between sectors to solve problems and make use of tools and methodologies capable of improving knowledge and ensuring business competitiveness. In addition, it is evident that their employees are able to apply new knowledge in their practical work on a daily basis. Complementing Racap, we verified the companies' abilities to apply knowledge, in which the insertion of new processes, products, or services in the market was evident. Companies develop prototypes, transform innovative ideas into solutions and patents, reconsider technologies, and adapt them according to new knowledge.

Pacap and Racap are interactive, with each of their components contributing to the development of the other, and the interactions between dimensions bring the Acap concept to life (Koçoglu et al., 2015). In the context of the ICT SMEs investigated in this study, both Acap (acquisition, assimilation, transformation, and application) and IOL processes occur in stages that are interrelated. The acquisition and assimilation capacities (Pacap) that provide the absorption of new knowledge present learning processes that support the Racap, since they start the reflection, discussion, and development of new knowledge. Finally, Racap, which refers to the legitimation of new knowledge, understands all previous procedural flows, being interrelated with the acquisition, as it incorporates the new knowledge that becomes part of the company's routine, creating new processes and practices. Subsequently, when confirming the hypotheses of the positive relationship between IOL, and Racap and Pacap, we highlight the interrelation between the dimensions of Acap and its dependence on IOL flows in SMEs. 


\subsection{Discussion of the fesults}

The literature proposes that the construction of Acap is based on learning processes that are directed toward the acquisition, assimilation, transformation, and application of external knowledge (Lane et al., 2006; Camisón \& Forés, 2010). Following this logic, the formation and development of Acap will also depend on the consolidation of a learning environment in the organization, in which the learning practices would stand out (Gebauer et al., 2012). Interorganizational relations are capable of influencing the level of development of new skills, and have a strong influence on the development of Acap. In an interorganizational relationship, each partner company brings the collaboration of a set of skills and prior knowledge (Dutta, 2012). Both absorption capacities, potential and realized, are cumulative and depend on IOL, as evidenced in the results of this study.

Organizations' efforts are directed to develop Acap in one period and make it easier to accumulate in the next (Cohen \& Levinthal, 1990). Thus, the Acap is not static, but it evolves through learning processes (Todorova \& Durisin, 2007), which were evidenced in this research from the practices of the investigated SMEs.

Based on the theoretical perspective of IOL supported by networking, Ernst's research (2010) showed that the performance of an organization is significantly increased by its centrality in the network. From shared learning opportunities, knowledge transfer, and information exchange, the acquisition and use of new knowledge become key mechanisms for IOL. It is noticed that, from the interaction with strategic partners, new opportunities arise, strengthening the sector's competitiveness.

A study carried out with organizations in the ICT sector in the USA showed that knowledge flows are strengthened in the advanced stages of relationship with strategic partners, increasing the capacity of companies to identify and assimilate knowledge. The results reinforce that a technology company's Acap is directly related to IOL (Schildt et al., 2012).

In an investigation carried out with companies from Brazil, China, and South Africa, the role of relationship networks was found to be a determining factor in the learning process and in the insertion of companies in different markets. The performance in networks is relevant to the growth of technology companies belonging to these emerging countries (Zonta \& Amal, 2017).

In this research, corroborating with the findings of the aforementioned surveys, it became evident that IOL in the environment of technology SMEs is strengthened by collaborating in networks with other organizations from 
the same sector. The practice of working in networks to update and develop existing methodologies and technologies in companies was evident. We found that companies have the perception that products and services produced and used cooperatively and in a network are more effective, and strengthen the strategy of organizations.

The results of this research provided support for the understanding that IOL in the environment of SMEs in the ICT sector is fundamental for the development of new capacities, observed in this study by the Acap. The findings of this research may contribute to the discussion of Acap in the SME environment, which is still under explored (Cassol et al., 2016; Koerich \& Cancellier, 2017; Cassol et al., 2019), as well as expand the investigation in economies of emerging countries, such as Brazil (Flatten et al., 2011).

The present research also contributed to the construction of a theoretical body with the existing research (Lane et al., 2006; Camisón \& Forés, 2010; Melkas, Uotila, \& Kallio, 2010; Flatten et al., 2011; Mukherji \& Silberman, 2013; Koçoglu et al., 2015), enhancing the understanding of how to promote Acap, supported by learning processes.

\section{FINAL CONSIDERATIONS}

This investigation explored the relationship between IOL and Acap in the environment of ICT SMEs. The hypothesis tests showed the existence of a positive influence of IOL on Pacap and Racap.

The study also found that, even in SMEs, the learning generated can increase the capacity of organizations to absorb something new. Once knowledge is understood and incorporated, it raises the level of existing knowledge in the organization, thus expanding the possibilities of IOL, as evidenced by confirming the research hypotheses. However, we emphasize that Acap and IOL differ between organizations. Although the source of knowledge is the same for the organizations present in the network, the intraorganizational environment and its internal characteristics impact the way in which new knowledge is received and used.

Finally, since the conceptual base of Acap has been built by various authors as an organizational practice and has been enriched with new elements from empirical studies, we seek with this study to make the discussion about Acap and IOL more consistent in Brazilian organizations, providing new insights, and contributing to the academic and managerial environment. 
Some limitations evidenced in this study can be identified from the quantitative perspective, which does not provide detailed disclosure of practices present in organizations. Those that were investigated are inserted in an environment which has characteristics that are particular to the state of Santa Catarina, regarding the formalization of an ecosystem directed to innovative development. For future studies, we suggest using the conceptual base of IOL and its relationship with Acap in the environment of SMEs present in other Brazilian states, as well as in other developing economies, in order to investigate the influence of OL practices in the formation of new competences, such as Acap.

\section{APRENDIZAGEM INTERORGANIZACIONAL E CAPACIDADE ABSORTIVA: INVESTIGAÇÃO EM PEQUENAS E MÉDIAS EMPRESAS}

\section{RESUMO}

Objetivo: Esta pesquisa analisa a influência da aprendizagem interorganizacional (AIO) sobre a capacidade absortiva (Acap), potencial (Pacap) e realizada (Racap), no ambiente de pequenas e médias empresas (PMEs). Originalidade/valor: O estudo contribuiu para o entendimento e a expansão das pesquisas da AIO operacionalizadas por meio dos elementos da Acap. A compreensão desses elementos é fundamental para o desenvolvimento de novas competências das PMEs brasileiras e/ou de países emergentes, imersas em setores dinâmicos e de alta mobilidade tecnológica, para se adaptarem e desenvolverem novas capacidades dinâmicas. Design/metodologia/abordagem: A pesquisa foi realizada por meio de uma survey em uma amostra de 215 PMEs do setor de tecnologia da informação e comunicação (TIC) no estado de Santa Catarina, Brasil. Os dados foram analisados a partir da técnica de modelagem de equações estruturais.

Resultados: Os resultados demonstraram que as relações de AIO são capazes de influenciar o desenvolvimento de novas competências e possuem forte influência sobre o desenvolvimento da Acap. A habilidade das organizações em adquirir, assimilar, aplicar e internalizar os conhecimentos disponíveis no setor, por meio de relações interorganizacionais, foi fundamental para a adaptação e sobrevivência. 


\section{PALAVRAS-CHAVE}

Aprendizagem organizacional. Aprendizagem interorganizacional. Capacidade absortiva. Pequenas e médias empresas. Setor de tecnologia da informação e comunicação.

\section{$\int$ REFERENCES}

Apriliyanti, I. D., \& Alon, I. (2017). Bibliometric analysis of absorptive capacity. International Business Review, 26(5), 896-907. doi:10.1016/j.ibusrev. 2017.02.007

Argote, L., \& Ophir, R. (2002). Intraorganizational learning. In J. A. C. Baum (Ed.), The Blackwell companion to organizations (pp. 181-207). Oxford: Blackwell Business.

Caccia-Bava, M. D., Guimarães, T., \& Harrington, S. J. (2006). Hospital organization culture, capacity to innovate and success in technology adoption. Journal of Health Organization and Management, 20(3), 194-217. doi:10.1108/14777260610662735

Camisón, C., \& Forés, B. (2010). Knowledge absorptive capacity: New insights for its conceptualization and measurement. Journal of Business Research, 63(7), 707-715. doi:10.1016/j.jbusres.2009.04.022

Cassol, A., Gonçalo, C. R., \& Ruas, R. L. (2016). Redefining the relationship between intellectual capital and innovation: The mediating role of absorptive capacity. BAR-Brazilian Administration Review, 13(4), 2-25. doi:10.1590/ 1807-7692bar2016150067

Cassol, A., Zanesco, D., Martins, C. B., \& Marietto, M. L. (2019). Capacidade absortiva como moderadora da relação entre inovatividade organizacional e desempenho inovador de pequenas e médias empresas brasileiras. Interciencia, 44(1), 15-22.

Child, J. (2001). Learning through strategic alliance. In M. Dierkes, A. B. Antal, J. Child, \& I. Nonaka (Eds.), Handbook of organizational learning and knowledge (pp. 657-680). Oxford: Oxford University Press.

Cohen, W. M., \& Levinthal, D. A. (1990). Absorptive capacity: A new perspective on learning and innovation. Administrative Science Quarterly, 35(1), 128-152. doi:10.2307/2393553 
Cooper, C. L., \& Rousseau, D. M. (Eds.). (1999). Trends in organizational behavior: The virtual organization (Vol. 6). New York: Wiley.

Crossan, M. M., Lane, H. W., \& White, R. E. (1999). An organizational learning framework: From intuition to institution. Academy of Management Review, 24(3), 522-537. doi:10.5465/AMR.1999.2202135

Crossan, M. M., Mauer, C. C., \& White, R. E. (2011). Reflections on the 2009 AMR decade award: Do we have a theory of organizational learning? Academy of Management Review, 36 (3), 446-460. doi:10.5465/amr.2010.0544

Dutta, D. K. (2012). Inter-organizational relationships and firm performance: Impact of complementary knowledge and relative absorptive capacity. Journal of Management Policy and Practice, 13(2), 46-55.

Easterby-Smith, M., \& Lyles, M. A. (Eds.). (2011). Handbook of organizational learning and knowledge management. Chichester: Wile.

Ernst, D. (2010). Upgrading through innovation in a small network economy: Insights from Taiwan's IT industry. Economics of Innovation and New Technology, 19(4), 295-324. doi:10.1080/10438590802469560

Faul, F., Erdfelder, E., Lang, A. G., \& Buchner, A. (2007). G*Power 3: A flexible statistical power analysis program for the social, behavioral, and biomedical sciences. Behavior Research Methods, 39(2), 175-191. doi:10.37 58/BF03193146

Ferreira, G. C., \& Ferreira, J. J. (2017). Absorptive capacity: An analysis in the context of Brazilian family firms. Revista de Administração Mackenzie, 18(1), 174-204. doi: 10.1590/1678-69712017/administracao.v18n1p174-204

Fiol, C. M., \& Lyles, M. A. (1985). Organizational learning. Academy of Management Review, 10(4), 803-813.

Flatten, T. C., Engelen, A., Zahra, S. A., \& Brettel, M. (2011). A measure of absorptive capacity: Scale development and validation. European Management Journal, 29(2), 98-116. doi:10.1016/j.emj.2010.11.002

Flatten, T. C., Greve, G. I., \& Brettel, M. (2011). Absorptive capacity and firm performance in SMEs: The mediating influence of strategic alliances. European Management Review, 8(3), 137-152. doi:10.1111/j.1740-4762. 2011.01015.x

Fletcher, M., \& Prashantham, S. (2011). Knowledge assimilation processes of rapidly internationalizing firms: Longitudinal case studies of Scottish SMEs. Journal of Small Business and Enterprise Development, 18(3), 475-501. doi:10.1108/14626001111155673 
Fredrich, V., Bouncken, R. B., \& Kraus, S. (2018). The race is on: Configurations of absorptive capacity, interdependence and slack resources for interorganizational learning in coopetition alliances. Journal of Business Research, 101, 862-868. doi:10.1016/j.jbusres.2018.11.038

Gebauer, H., Worch, H., \& Truffer, B. (2012). Absorptive capacity, learning processes and combinative capabilities as determinants of strategic innovation. European Management Journal, 30(1), 57-73. doi:10.1016/j.emj. 2011.10.004

Hair J. F., Jr., Black, W. C., Babin, B. J., Anderson, R. E., \& Tatham, R. L. (2009). Análise multivariada de dados. Porto Alegre: Bookman.

Hair J. F., Jr., Hult, G. T. M., Ringle, C., \& Sarstedt, M. (2016). A primer on partial least squares structural equation modeling (PLS-SEM). Los Angeles: Sage.

Hair J. F., Jr., Sarstedt, M., Hopkins, L., \& G. Kuppelwieser, V. (2014). Partial least squares structural equation modeling (PLS-SEM). European Business Review, 26(2), 106-121. doi:10.1108/ebr-10-2013-0128

Henseler, J., Ringle, C. M., \& Sinkovics, R. R. (2009). The use of partial least squares path modeling in international marketing. In R. R. Sinkovics \& P. N. Ghauri (Eds.). New challenges to international marketing. Bingley, UK: Emerald Group. doi:10.1108/S1474-7979(2009)0000020014

Hernández-Perlines, F., Moreno-García, J., \& Yañez-Araque, B. (2016). The mediating role of competitive strategy in international entrepreneurial orientation. Journal of Business Research, 69(11), 5383-5389. doi:10.1016/ j.jbusres.2016.04.142

Holmqvist, M. (2003). A dynamic model of intra-and interorganizational learning. Organization Studies, 24(1), 95-123. doi:10.1177/017084060302 4001684

Ireland, R. D., Hitt, M. A., \& Vaidyanath, D. (2002). Alliance management as a source of competitive advantage. Journal of Management, 28(3), 413-446. doi:10.1016/S0149-2063(02)00134-4

Jain, S., Kashiramka, S., \& Jain, P. K. (2018). Impact of organizational learning and absorptive capacity on the abnormal returns of acquirers: Evidence from cross-border acquisitions by Indian companies. Global Journal of Flexible Systems Management, 19(4), 289-303. doi:10.1007/s40171-018-0193-9

Jansen, J. J., Van Den Bosch, F. A., \& Volberda, H. W. (2005). Managing potential and realized absorptive capacity: How do organizational antecedents matter? Academy of Management Journal, 48(6), 999-1015. doi:10.1007/BF03396721 
Jiménez-Jiménez, D., \& Sanz-Valle, R. (2011). Innovation, organizational learning, and performance. Journal of Business Research, 64(4), 408-417. doi:10.1016/j.technovation.2010.12.002

Jones, O., \& Macpherson, A. (2005). Power and inter-organizational learning: Intertwining new knowledge [Working Paper]. Manchester Metropolitan University Business School, Manchester, UK.

Jung-Erceg, P., Pandza, K., Armbruster, H., \& Dreher, C. (2007). Absorptive capacity in European manufacturing: a Delphi study. Industrial Management \& Data Systems, 107(1), 37-51. doi:10.1108/02635570710719043

Koçoglu, I., Akgün, A. E., \& Keskin, H. (2015). The differential relationship between absorptive capacity and product innovativeness: A theoretically derived framework. International Business Research, 8(7), 108. doi:10.5539/ ibr.v8n7p108

Koerich, G. V., \& Cancellier, E. L. P. de L. (2017). Capacidade de absorção: Levantamento e análise de pesquisas quantitativas e principais constructos relacionados. Seminários de Administração, São Paulo, SP, Brasil, 20.

Koerich, G. V., Cancellier, É. L. P., \& Tezza, R. (2015). Capacidade de absorção, turbulência ambiental e desempenho organizacional: Um estudo em empresas varejistas catarinenses. Revista de Administração Mackenzie, 16(3), 238. doi:10.1590/1678-69712015/administracao.v16n3p238-267

Lane, P. J., Koka, B. R., \& Pathak, S. (2006). The reification of absorptive capacity: A critical review and rejuvenation of the construct. Academy of Management Review, 31 (4), 833-863. doi:10.5465/AMR.2006.22527456

Larsson, R., Lars Bengtsson, K. H., \& Sparks, J. (1998). The interorganizational learning dilemma: Collective knowledge development in strategic alliances. Organization Science 9(3), 285-305. doi:10.1287/orsc.9.3.285

Leal-Rodríguez, A. L., Ariza-Montes, J. A., Roldán, J. L., \& Leal-Millán, A. G. (2014). Absorptive capacity, innovation and cultural barriers: A conditional mediation model. Journal of Business Research, 67(5), 763-768. doi:10.1016/ j.jbusres.2013.11.041

Lowry, P. B., \& Gaskin, J. (2014). Partial least squares (PLS) structural equation modeling (SEM) for building and testing behavioral causal theory: When to choose it and how to use it. IEEE Transactions on Professional Communication, 57(2), 123-146. doi: 10.1109/TPC.2014.2312452

Melkas, H., Uotila, T., \& Kallio, A. (2010). Information quality and absorptive capacity in service and product innovation processes. Interdisciplinary Journal of Information, Knowledge, and Management, 5, 357-374. 
Mozzato, A.R., \& Bitencourt, C. C. (2014). Understanding interorganizational learning based on social spaces and learning episodes. Brazilian Administration Review, 11(3), 284-301. doi:10.1590/1807-7692bar2014370

Mozzato, A. R., Bitencourt, C. C., \& Grzybovski, D. (2015). The interorganizational level in the learning continuum: Analytic conceptual scheme. International Business Research, 8(4), 94. doi:10.5539/ibr.v8n4p94

Mukherji, N., \& Silberman, J. (2013). Absorptive capacity, knowledge flows, and innovation in US metropolitan areas. Journal of Regional Science, 53(3), 392-417. doi:10.1111/jors.12022

Nonaka, I., \& Von Krogh, G. (2009). Perspective tacit knowledge and knowledge conversion: Controversy and advancement in organizational knowledge creation theory. Organization science, 20(3), 635-652. doi:10.1287/orsc. 1080.0412

Oliveira, S. R., \& Balestrin, A. (2018). Cooperação universidade-empresa: Um estudo do projeto Unisinos - HT Micron para o desenvolvimento de capacidade absortiva na área de semicondutores. Gestão \& Produção, 25(3), 595-609. doi:10.1590/0104-530x1018-13

Otto, P. (2012). Dynamics in strategic alliances: A theory on interorganizational learning and knowledge development. International Journal of Information Technologies and Systems Approach, 5(1), 74-86. doi:10.4018/ jitsa.2012010105

Patterson, W., \& Ambrosini, V. (2015). Configuring absorptive capacity as a key process for research intensive firms. Technovation, 36, 77-89. doi:10.10 16/j.technovation.2014.10.003

Picoli, F. R., \& Takahashi, A. (2016). Capacidade de absorção, aprendizagem organizacional e mecanismos de integração social. Revista de Administração Contemporânea, 20(1), 1-20. doi:10.1590/1982-7849rac2016140036

Rea, J., \& Parker, A. (2000). Metodologia da pesquisa em ciências sociais. São Paulo: Pioneira \& Thompson.

Ringle, C. M., Sarstedt, M., \& Straub, D. (2012). A critical look at the use of PLS-SEM. MIS Quarterly, 36, 3-14. Recuperado de http://www.jstor.org/ stable/41410402

Ringle, C. M., Silva, D., \& Bido, D. D. S. (2014). Modelagem de equações estruturais com utilização do SmartPLS. Revista Brasileira de Marketing, 13(2), 56-73. doi: 10.5585/remark.v13i2.2717

Ringle, C. M., Wende, S., \& Will, A. (2005). Smart PLS 2.0 M3. Hamburg: University of Hamburg. 
Schildt, H., Keil, T., \& Maula, M. (2012). The temporal effects of relative and firm-level absorptive capacity on interorganizational learning. Strategic Management Journal, 33(10), 1154-1173. doi:10.1002/smj.1963

Serviço Brasileiro de Apoio às Micro e Pequenas Empresas (2017). Anuário do trabalho nos pequenos negócios: 2015. Brasília, São Paulo: Sebrae. Recuperado de https://www.dieese.org.br/anuario/2017/anuarioDosTrabalhadores PequenosNegocios.pdf

Song, Z. (2015). Organizational learning, absorptive capacity, imitation and innovation: Empirical analyses of 115 firms across China. Chinese Management Studies, 9(1), 97-113. doi:10.1108/CMS-05-2014-0092

Sparrow, J., Tarkowski, K., Lancaster, N., \& Mooney, M. (2009). Evolving knowledge integration and absorptive capacity perspectives upon university-industry interaction within a university. Education and Training, 51 (8), 648-664. doi:10.1108/00400910911005217

Teece, D., Pisano, G., \& Shuen, A. (1997). Dynamic capabilities and strategic managerial. Strategic Managerial Journal, 18(7), 509-533. doi:10.1002/ (SICI) 1097-0266(199708) 18:7<509::AID-SMJ882>3.0.CO;2-Z

Teixeira, E. K., Oliveira, M., \& Curado, C. M. M. (2018). Knowledge management process arrangements and their impact on innovation. Business Information Review, 35(1), 29-38. doi:10.1177/0266382118757771

Todorova, G., \& Durisin, B. (2007). Absorptive capacity: Valuing a reconceptualization. Academy of Management Review, 32(3), 774-786. doi:10.5465/AMR.2007.25275513

Tracey, P., \& Clark, G. L. (2003). Alliances, networks and competitive strategy: Rethinking clusters of innovation. Growth and Change, 34(1), 1-16. doi:10. $1111 / 1468-2257.00196$

Valentin, S. M. F. A. (2010). Aprendizagem como estoques e fluxos de conhecimento em organizações que integram redes de informação e conhecimento científico em saúde (Dissertação de mestrado, Universidade Presbiteriana Mackenzie, São Paulo, Brasil).

Vinding, A. L. (2006). Absorptive capacity and innovative performance: A human capital approach. Economics of Innovation and New Technology, 15(4-5), 507-517. doi: 10.1080/10438590500513057

Wang, C. F., \& Zhang, P. (2009). An empirical study on the relationship between properties of knowledge, network topology and corporation innovation performance. International Conference on Management Science and Engineering, Moscow. doi: 10.1109/ICMSE.2009.5318085 
Wetzels, M., Odekerken-Schröder, G., \& Van Oppen, C. (2009). Using PLS path modeling for assessing hierarchical construct models: Guidelines and empirical illustration. MISQuarterly,33(1),177-195.doi:10.2307/20650284

Zahra, S. A., \& George, G. (2002). Absorptive capacity: A review, reconceptualization, and extension. Academy of Management Review, 27(2), 185-203. doi:10.5465/amr.2002.6587995

Zonta, T. C., \& Amal, M. (2017). Institutions, networks and the international growth of born globals from emerging markets. Anais do XLI Encontro da Anpad, São Paulo, SP, Brasil.

\section{AUTHOR NOTES}

Alessandra Cassol, PhD from the Postgraduate Program in Administration (PPGA), Nove de Julho University (Uninove); Márcio L. Marietto, PhD from the PPGA-Uninove; Graciele Tonial, master from the Postgraduate Program in Administration (PPGA), University of Vale do Itajaí (Univali); Nathalia B. Werlang, PhD from the Postgraduate Program in Administration (PPGA), Federal University of Santa Catarina (UFSC).

Alessandra Cassol is now professor and coordinator at the Professional Master's Program in Administration (PMPA) of University of Contestado (UnC); Márcio L. Marietto is now researcher and full professor at the Department globADVANTAGE - Center of Research in International Business \& Strategy of Polytechnic Institute of Leiria (ESTG); Graciele Tonial is now full professor at the Department of Management of University of Western Santa Catarina (Unoesc); Nathalia B. Werlang is now researcher and full professor at the Department of Management of FAI University Center (UCEFF).

Correspondence concerning this article should be addressed to Alessandra Cassol, Rua Victor Sopelsa, 3000 (Coordenação PMPA), Salete, Concórdia, Santa Catarina, Brazil, CEP 89711-330. E-mail: alessandracassol.adm@gmail.com

EDITORIAL BOARD

Editor-in-chief

Gilberto Perez

Associated editor

Gloria Charão Ferreira

Technical support

Vitória Batista Santos Silva
EDITORIAL PRODUCTION

Publishing coordination

Jéssica Dametta

Layout designer

Emap

Editorial intern

Paula Di Sessa Vavlis

Graphic designer

Libro

Language editor

Daniel de Almeida Leão 